ARTICLE HISTORY: Received: March 17, 2021 Accepted: May 12, 2021 Published: May 19, 2021

КОНКУРЕНТНОЕ ПРЕИМУЩЕСТВО ИНОСТРАННЫХ ЯЗЫКОВ.

\author{
Шойимкулова Махзуна Шавкатовна \\ стариий преподаватель, кафедра Иностранные языки \\ Бухарский инженерно-технологический институт, \\ Республика Узбекистан, г.Бухара
}

\title{
THE COMPETITIVE ADVANTAGE OF FOREIGN LANGUAGES.
}

\author{
Shoyimkulova Mahzuna Shavkatovna \\ a senior teacher of English, Department of Foreign Languages \\ Bukhara engineering technological institute \\ Republic of Uzbekistan, Bukhara
}

\begin{abstract}
Аннотация. Актуальность иностранных языков в подготовке конкурентно способных специалистов, их роль в будущей карьере инженеров, требование к учителям и пути стимуляции и поощрения обсуждаются в этой статье. Также выдвигаются ряд предложений улучшения эффективной работы учителей.

Abstract. The importance of foreign languages in preparing competitive specialists, role of languages in the career of future engineers, demands to teachers, ways of teachers' stimulation and rewards are discussed in this articles. Suggestions for improving teachers work are put forward.

Ключевые слова: зарубежный и местный опыт, конкурентоспособность, обмен студентами, рынок труда, международные стандарты, нужды обучающихся.

Keywords: foreign and native experience, competitiveness, students exchange, learners' needs, labor market, international standards.
\end{abstract}

A study of foreign and national research shows that the concept of "competitiveness" of students currently being interpreted in a very broad sense. Moreover, it has become a permanent feature in the field of educational services and market relations.

Student competitiveness encompasses issues between employers, job seekers, graduates, and higher education institutions in this field.

In the mid-1990s, large-scale research was conducted with the support of the European Social Fund, which supplemented not only the current technical requirements of the market, but also the needs of young people in professional attractiveness, developed organizational and didactic opportunities and conditions for qualification. It is also proposed to deepen foreign languages, legal and economic sciences [1-3].

Knowledge of foreign languages is one of the opportunities to ensure the competitiveness of professionals in the labor market. Therefore, the issue of teaching foreign languages for special purposes is of particular importance today, because foreign languages are not only a means of obtaining information from scientific sources, but also allow future professionals in various fields to use modern information, science and technology, which creates an opportunity to deepen and expand their professional competence [4].

Today, a foreign language has become a means of communication for professionals, and has become one of the important criteria for international exchange of specialists, foreign internships, as well as study and work at prestigious universities abroad. The purpose of learning foreign languages is to create communicative competence, in which we mean the exchange of ideas in different situations using language norms during the dialogue. The peculiarity of teaching foreign languages for professional purposes is that this process is carried out in close connection with the dialogue of professional orientation. At the same time, language teachers need to ask ourselves the following questions:

Why do we need a foreign language?

Who is the foreign language used to communicate with?

What should consist of the context of a foreign language?

From these three questions, our purpose is determined. Of course, the peculiarity of teaching a foreign language for special purposes is that it must take into account the needs of language learners, the labor market, international standards and needs. And compliance with these requirements will ensure the exchange of professionals in an academic and business environment [5-8].

In setting the next goal, the main emphasis should be on the practical skills of the language. Because it is no secret that no one benefits from the information taught if it is not put into practice. For a specialist, language is necessary in communicating with his/her foreign colleagues, translating working papers, acting as a translator in production, reading 
newspapers and magazines. Physicians use the language context directly in medical facilities, in engineering, in factories, and in journalists, depending on how and in what field they receive and present information [9-10].

Particularly it is the context of the language that defines the purpose of language teaching. A more immediate goal is to use information and communication technologies to develop communicative competencies, which can also be a solution to language learning problems.

Listening to and understanding authentic texts creates a real language-speaking environment for students. Of course, the realization of any goal depends on the degree of interaction between the teacher and the student, who are the subjects of the educational process [11].

I also think it is necessary to dwell on some of the problems we face in order to achieve the goal. Teaching foreign languages to students of higher education, as well as teachers of special subjects, has become both a requirement and a necessity of the time. On the one hand, in learning a foreign language in some specialists while his/her age and ability hinder it, in most cases it is due to teachers' lack of free time for language learning or lack of proper planning.

For two or three years, classes have been organized for teachers during the holidays. Is learning a foreign language effective during a 10-day vacation?

No.

In this regard, I would like to make a few suggestions.

First of all, foreign language courses should be defined as a mandatory and continuous course for 3 or 6 months, not during the holidays, and as a final step, the learner must pass a test and receive a certificate confirming the level of English language proficiency.

Second, motivate the teacher who conducts the lesson based on the outcome of the group of listeners who conducted the lesson. This serves as both a motivation and a stimulus for the teacher.

Third, to add a certain percentage increase to the monthly salary of teachers of special subjects with high results in a foreign language.

Fourth, I believe that additional points should be allocated for teachers who teach a foreign language in order 105 or 246. If these points are determined based on the number of those who have received a certificate from the audience.

Fifth, teachers who teach will be exempted from additional work because re-teaching after 3 pairs of classroom hours will reduce the effectiveness of the teacher's teaching. In order for a teacher to be ready for a lesson, he needs time, thorough preparation, to ensure the effectiveness of his lesson.

There is a saying a good lesson is a good work. If we want every lesson to be like this, we need to give the teacher a chance to prepare for the lesson. Otherwise how can we demand lesson quality from the teacher.

We require a foreign language teacher to translate foreign literature for special subjects, to hold various events, to cooperate with the school, and at the same time to provide quality lessons. Is it possible to adequately prepare for a lesson with such employment? It is the most important task and duty of every teacher to teach his / her lesson well and to provide quality knowledge to the student. But in order to fulfill this task, it is necessary to create opportunities and conditions for him to be adequately prepared for the lesson.

As the role of foreign languages in the training of competitive specialists grows, our main goal should be to train in our country a specialist who can study the foreign language, who can be among the world's leading scientists.

\section{References}

1. Пробин П.С. Поликультурное образование как социально-педагогическое явление в контексте проблематики межкультурной коммуникации // Человек и культура. 2015. № 1. С.1-21.

2. Русанов Е.К. Характеристика специалистов с иноязычной компетентностью на современном российском рынке труда //Молодой ученый. 2011. № 11. Т. 2. С. 99-101.

3. Соловова Е. Н. Методика обучения иностранному языку : Базовый курс лекций. М. : Просвещение, 2003.

4. Перфилова Т. В. Примерная программа по дисциплине «Иностранный язык для подготовки бакалавров (неязыковые вузы)». М. : ИПК МГЛУ РЕМА, 2011.

5. Salomova Malika Zohirovna, An analysis of artistic aesthetics in Oscar Wilde's portrait of Dorian Grey. International Scientific Journal Theoretical and Applied Science. Philadelphia, USA. 21.04.2020.

6. Salomova Malika Zohirovna, Linguocultural aspect of foreign language words of youth jargon. International journal on integrated education. Индонезия. 2020.

7. Salomova Malika Zohirovna, MODERN TECHNOLOGIES OF TEACHING FOREIGN LANGUAGE. Journal Impact Factor 2020 for JournalNX. India. 2020.

8. Sharipova Feruza Negmatulloyevna. THE BASIC FEATURES OF TEACHING A FOREIGN LANGUA. Journal Impact Factor 2020 for JournalNX. India. 2020.

9. Sharipova Feruza Negmatulloyevna. TEACHING VOCABULARY AS AN IMPORTANT WAY OF LEARNING LANGUAGE. International Journal on Integrated Education.

10. Sharipova Feruza Negmatulloyevna. THE MAIN DIFFICULTIES IN LEARNING A FOREIGN LANGUAGE. International Journal on Integrated Education. 
11. Shoyimkulova M.Sh.. USE OF INFORMATION TECHNOLOGIES IN FOREIGN LANGUAGE. Journal Impact Factor 2020 for JournalNX. India. 